\title{
Correction to: Design, characterization, and manufacturing of circular bellows pneumatic soft actuator
}

\author{
Tariq Rehman ${ }^{1,2}$ - Ahmad Athif Mohd Faudzi ${ }^{1,3}$ • Dyah Ekashanti Octorina Dewi ${ }^{4}$. \\ Mohamed Sultan Mohamed Ali ${ }^{1}$
}

Published online: 25 October 2017

(C) Springer-Verlag London Ltd. 2017

\section{Correction to: Int J Adv Manuf Technol \\ https://doi.org/10.1007/s00170-017-0891-z}

The original version of this article unfortunately contained a mistake. The name of the corresponding author was incorrectly written as "Mohamad Sultan Mohamad Ali". The correct name should be "Mohamed Sultan Mohamed Ali".

The online version of the original article can be found at https://doi. org/10.1007/s00170-017-0891-z.

\footnotetext{
Mohamed Sultan Mohamed Ali sultan_ali@fke.utm.my

1 Faculty of Electrical Engineering, Universiti Teknologi Malaysia, 81310 Skudai, Johor, Malaysia

2 Department of Electronic Engineering, NED University of Engineering and Technology, Karachi 75270, Pakistan

3 Center for Artificial Intelligence and Robotics (CAIRO), Universiti Teknologi Malaysia, Jalan Semarak, 54100 Kuala Lumpur, Malaysia

4 Faculty of Biosciences and Medical Engineering, Universiti Teknologi Malaysia, 81310 Skudai, Johor, Malaysia
} 